\title{
Chapter 2 \\ Trouble in the Homeland: How Cultural \\ Identity and Welfare Politics Merge \\ in Contemporary Danish and Swedish \\ Politics
}

\author{
Anders Hellström and Mahama Tawat
}

\subsection{Introduction}

The welfare systems of Denmark and Sweden contain many similar socio-economic features. According to Esping-Andersen (1990), they are ideal examples of Social Democracy, with universal access to welfare provisions, the absence of stratification, a high level of decommodification or the extent of welfare provisions in relation to previous earnings during periods of employment, and with corporatist agreements between trade unions, employers, and the state. However, Denmark and Sweden espouse two distinctively different discourses on immigration and integration. The aim of this chapter is to analyze the conventional discourses at the intersection of welfare, culture, and immigration and determine how they are reflected in different opinion communities. Specifically, we ask what meanings are embedded in the different political discourses. What is acceptable to say in one context may not necessarily be the case in another, as the borders of what is considered normality differ.

We draw from the work of Anthropologist Claudia Strauss (2012), whose relevant book, Making Sense of Public Opinion, shows how discourses disseminated in opinion communities are built around distinctive cultural schemas. In other words, they are "simplified understandings" (Strauss, p. 17) about the historical heritage of the nation-of what immigrants are like, how they behave, what preferences they

\footnotetext{
A. Hellström ( $\square)$

Malmö Institute for Studies of Migration, Diversity and Welfare, Malmö University, Malmö, Sweden

e-mail: anders.hellstrom@mau.se

M. Tawat

Higher School of Economics, Moscow, Russian Federation

Malmö Institute for Studies of Migration, Diversity and Welfare, Malmö University,

Malmö, Sweden
} 
have, and how they comprehend gender relations. Our empirical materials are drawn from the government policy strategy, "Culture for All: Culture in the Whole Country" (Kultur for alle: Kultur i hele landet), the Cultural Canon (Kultur Kanon), and the Danish Canon (Danmark Kanon) as well as the parliamentary debate on the government bill in Sweden called Culture for All (Kultur för alla). In Denmark, decision-making in cultural policy rests upon the incumbent government and is not routinely debated in parliament; thus, the formats of our selected materials differ.

In addition to examining the aforementioned empirical materials, we explore the Facebook community of Martin Henriksen, who is a high-ranking official of the right-wing populist Danish People's Party (Dansk Folkeparti, DF) and was an elected member of parliament (Folketing) for the Danish People's Party between 2005 and 2019. In the Swedish case, we examine the blog community of Therese Borg, a prominent member of the anti-immigration, right-wing populist party, Sweden Democrats (Sverigedemokraterna, SD). Borg was a member of the municipal council of Klippan, a small town in southern Sweden, and is a member of the party's executive committee. The chapter proceeds as follows: The following section gives a background to the development of political discourses on immigration in Denmark and in Sweden. Section two elaborates on the conceptual framework, while section three gives an analysis of the policy arena in Denmark and Sweden. This is followed by an analysis of the blogospheres in Denmark and Sweden.

\subsubsection{Background}

At the end of the nineteenth century, Sweden and Denmark were countries of emigration primarily to North America. However, the extent of this emigration was far less in Denmark than in Sweden, where it is estimated that approximately one-fifth of the population emigrated to the United States in the late decades of the nineteenth century (Hellström 2016: 34). In 1930, Sweden became a country of net immigration far earlier than Denmark. Also, after the Second World War, with a booming economy and gaping labor shortages in their industries, labor migrants became the main component of immigration in both countries. However, with a decline in economic and industrial growth and the outbreak of the Oil Crisis, Sweden and Denmark stopped labor immigration respectively in 1972 and 1973. Thereafter, the two countries witnessed the progressive increase in the number of refugees and their families fleeing conflict or dictatorships from Eastern Europe, certain parts of Asia, the Middle East, and Africa. The numbers peaked during the Iran-Iraq wars in the 1980s, the wars in former Yugoslavia in the early 1990s, and Kosovo in the late 1990s.

The recent peak in 2016 is related to the Syrian conflict that, in the summer 2015, forced more than one million refugees to seek abode in Europe, mainly Germany and Sweden. In contrast to Denmark-which, in the 1990s and most notably the early 2000s, moved with many other European countries toward the implementation 
of stricter policies regarding immigration, integration, and citizenship-Sweden went in the opposite direction.

Swedish exceptionalism ended on 12 November 2015, when the government enacted temporary border and ID controls between Denmark and Sweden to stem the influx of Syrian refugees. On 24 November of the same year, the government proposed a temporary law that would give all successful asylum seekers temporary rather than permanent residency. The legislation officially came into effect on 20 July 2016, and Sweden thereby lowered its standards to the EU level (Bevelander and Hellström 2019). Today, the proportion of immigrants in the Swedish population in 2019 was is $19,6 \%$ (SCB 2019), whereas in Denmark, the corresponding figure is $13 \%$ (Statistik Denmark 2019).

\subsection{Multiculturalism in the Welfare State}

Sweden adopted multiculturalism as its official policy in the early 1970s. Its first state cultural policy and first immigrant integration policy, which were passed respectively in 1974 and 1975, made the preservation and promotion of immigrants' cultures an unequivocal matter of state policy. Defining culture in the anthropological sense, as "a way of life, including traditions, food, religion, language," (Puri 2004, p. 24), ${ }^{1}$ it was argued that immigrants' home cultures were necessary not only for their well-being but also for enriching Swedish society. Since then, these policies have been reproduced more or less in the same terms. In contrast, Denmark did not adopt such policy, although the government at that time and its successors were aware of the developments in neighboring Sweden and of the legal requirement to inform if not consult each other on policy development (Tawat 2017). However, it was not until 2006, with the official adoption of a Culture Canon highlighting the main elements of Danish culture with which immigrants were encouraged to get acquainted, that an official policy was formulated.

Given that welfare permeates every aspect of social life as a contract of rights and obligations bestowed upon citizens from cradle to grave, it has become part of the national self-image and central to cultural policy regarding immigrants. As Hellström et al. write in the introduction to this volume, welfare policies are embedded in cultural notions of how the national community should be crafted and by whom. Nevertheless, attitudes vary among the population regarding immigration. These range from welfare chauvinism (i.e. welfare for the natives) to welfare for all, which includes the appraisal of multiculturalism.

Welfare chauvinistic claims argue that multicultural policies have negative effects on the welfare state (see Norocel 2016; Schierup et al. 2006). The first effect is "crowding-out" which consists of laying focus, energy and time on "soft" issues such as the numerical representation of minorities instead of "hard issues" such as

\footnotetext{
${ }^{1}$ The other definition of culture is aesthetics comprising arts, cinema, library, and theatre.
} 
economic redistribution (Banting and Kymlicka 2006, pp. 10-11). Whereas immigrants may benefit more from having equal opportunities as a result of structural change. The second effect is "corroding", where it is assumed that ethnocultural diversity undermines trust and solidarity (Banting and Kymlicka 2006, p. 11). As such, citizens are less likely to contribute to welfare schemes if they perceive that the beneficiary is not "one of them" but rather an immigrant or from a historic minority. In the same vein, it is argued that because most welfare arrangements result from reparations to historical injustices, they lead to a "politics of identity" or "politics of grievance" which undermines trust between groups. The third effect is "misdiagnosing". It is alleged that the problem of minorities is "economic marginalization not cultural misrecognition" and policies that are based on culture are inadequate to solve problems that are structural in nature (Banting and Kymlicka 2006, p. 13). For instance, multicultural education cannot alter wage differences between natives and immigrants. In our empirical analysis, we investigate the narratives around these themes in the parliamentary arena and in online communities.

\subsection{Political and Media Narratives}

A conventional discourse synthetizes and rationalizes all the various expressions on a particular issue reflected on the group and national levels (Strauss 2012). Hellström and Nilsson refer to these as rhetorical figures (2010, p. 56). However, people sometimes hold on to a repertoire of contradicting views and positions that do not necessarily follow congruent ideological lines or logical reasoning. As Pettersson explains, individuals do not identify with a congruent set of identity positions throughout life but rather often adopt contradictory points of identification. Class background, social milieu, formative experiences, gender, and ethnic affiliations spin a complex tapestry of identities (2017, pp. 35-36). From these data, one can find two types of discourse:

- Discourses from the policy arena.

In the Danish case, we examine the content of Culture for All (Kultur for alle), a policy enacted on 2 December 2009 by Culture Minister Carina Christensen (2008-2010), the Danish Cultural Canon published in 2006 by Brian Mikkelsen, Culture Minister for Denmark from 2001-2008 and the Danish Canon formulated by Bertel Haarder, Culture Minister from 2015 to 2016. As stated, the Danish mode of policymaking has often consisted of speeches to the Danish parliament (Folketing) or public statements. Some ministers launched elaborate policy projects, but these were not always debated in the parliament. In the Swedish case, we analyze the debate on the government bill, Culture for All (Kultur för alla), which has the same title as its Danish equivalent examined previously and which was held on 23 February 2017. 
- Discourses from the blogosphere.

Katarina Pettersson (2017, pp. 40-44) explains that blogging is an essential technique for promoting nationalist and anti-immigration ideas:

Blog entries provide useful insights into the rhetoric used by representatives of antiimmigrant parties, their followers, and other audiences. The opportunities to comment on the posts enable interaction and foster political mobilization. Together, these claims constitute a particular opinion community. Claims are delivered in the form of emotionally engaging stories or narratives through vivid powerful images.

The blog community serves as a platform for the dissemination of ideas and political participation by means of the collaborative and interactive features (Pettersson 2017, p. 10). In the communication, the position of mediator (such as journalists) connecting the sender and the receiver is eradicated (Hellström 2016, pp. 69-74). Mazzoleni and Bracciale (2018) have shown that mainstream policy claims and the mode of communication are disseminated in social media.

We study posts by Martin Henriksen of the Danish People's Party (DF) and Therese Borg from the Sweden Democrats (SD), including the comments made by their followers on matters pertaining to culture and welfare. Martin Henriksen of the DF is a member of the executive committee of his party. He was the DF representative on Immigration and Integration, and representative for the Danish minority in the German region of Schleswig-Holstein, which was lost in the aftermath of the 1864 Danish-German war. He has been a member of corresponding select committees when he was member of the Folketing. His Facebook page ${ }^{2}$ has a significant number of active followers, and he oftentimes engages in discussions with them. Therese Borg is a member of the SD party executive board and holds a chair in the local municipal council in Klippan, a town situated in the south of Sweden (although she recently stepped down from this post). She published frequently on her blog, ${ }^{3}$ and during the analyzed period, she was a chairperson on the party's national board. Her opinions and views are meaningful because they represent a bridge between the official politics of the SD and the views held by its sympathizers. We searched three sections on Borg's blog page associated with welfare issues. Each section included a number of replies from the public. These were Work/Unemployment Insurance Fund/Social Assistance (Arbete/A-Kassa/Försörjningsstöd) (five replies); Health, Medical Treatment and Patient Safety (Hälso- och sjukvård, patientsäkerhet) (20 replies); and Culture and Leisure (Kultur och fritid) (30 replies). In total, there were 635 blog entries.

\footnotetext{
${ }^{2}$ https://www.facebook.com/Martin-Henriksen-1604502423155684/

${ }^{3} \mathrm{https}: / /$ thereseborg.wordpress.com/
} 


\subsection{Analysis of the Policy Discourse in Denmark}

The policy discourse in Denmark on multiculturalism in the welfare state has been marked by criticism of its corroding effects more than its crowding out and misdiagnosing effects. That is, multiculturalism causes fragmentation and thus poses a threat to social cohesion and the sustainability of the welfare system. Following the center-right liberal-conservative victory in the November 2001 Danish general elections, the new liberal Prime Minister, Anders Fogh Rasmussen, appointed Brian Mikkelsen, from the conservative Party as Minister in charge of Culture. One of Mikkelsen's first actions was to lay down the Cultural Development Fund, set up by the Social Liberal Party in 2002. It was the only public institution that aimed to fund immigrants' cultural productions, although it was largely unsuccessful in achieving this goal. The institution's budget of DKK 5 million was re-allocated (Danish Ministry of Culture 2002). Then in 2006, Mikkelsen gathered seven committees headed by a lead expert and coordinated by Professor Jørn Lund with the purpose of formulating a canon of Danish culture (Kultur Ministeriet 2010). The canon was said to represent Danish culture. Its goals were to "serve as a compass showing the directions and milestones in Denmark's long and complex cultural history; serve as a platform for discussion and debate; provide reference points and awareness of what is special about Danes and Denmark in an ever more globalized world; and strengthen the sense of community by showing key parts of our common historical possessions"4 (Duelund 2009). Four months later at the Conservative Party annual conference, he returned to his initial argument that multiculturalism has corroding effects on the society that follows from immigration flows from Muslim countries "...when immigrants from Muslim countries refuse to recognize the Danish culture and European norms. In the midst of our own country, it is becoming a parallel society in which minorities practice their medieval norms and undemocratic ways of thinking" (Mikkelsen 2005).

The speech stirred strong reactions amongst the public. Lund asked for a clarification, and two members of the canon-drafting committee threatened to resign (Andersen 2005). The topic of what distinguishes Danish culture in relation to "Muslim culture" became a topic of controversy, and many felt the need to engage in critical dialogue with him. The newspaper Politiken quoted him as saying that "Yes, [Danish culture] is better. Yes. I am a declared opponent of value relativism because I think something is better than another" (Andersen 2005). A month later, in an interview to the newspaper Berlingske Tidende, he fully reinstated his claim that the canon was part of the fight to preserve Danish culture (Petersen 2006).

Published in 2006, the final canon project consisted of 96 items. Each of the following sectors was represented by 12 works: art, architecture, photography, design, sculpture, film, literature, and theatre. There were 24 works in the music sector, among which 12 were classical music pieces and 12 were popular music pieces. A Canon for children's culture was unveiled as well. A special website (www.kulturkanon.kum.

\footnotetext{
${ }^{4}$ https://www.culturalpolicies.net/web/compendium-topics.php?aid=149
} 
$\mathrm{dk}$ ), a booklet, and teaching materials on the Canon were made available in schools and public libraries. None of these works was authored by a non-Western immigrant or anyone who embodied the immigrant experience. The only work which referred to non-Western culture was Aladdin and the Wonderful Lamp (Aladdin, eller den forunderlige lampe), a portrait of Aladdin dating from 1805 and made by the artist Adam Oehlenschläger (1779-1850). The Canon well illustrates the discursive context in which the contemporary rhetoric on immigration is framed and is an example of the politics of assimilation (Banting and Kymlicka 2006). The conventional discourse encompasses the view that Danish culture is unique and reflects a unique people.

Since the initial policy change initiated by Mikkelsen, there has been remarkable continuity in Danish policy and politics, as shown by two of the ministerial policies that followed. The conventional discourse is thus to enable assimilation. However, this continuity has not been fluid but rather incremental in nature. Carina Christensen, a Conservative People's Party (Det Konservative Folkeparti, K) minister in charge of culture between 2008 and 2010 sought with her policy program Culture for All (Kultur for alle) published on 2 December 2009 to widen access to the Cultural Canon produced by Mikkelsen. A former culture spokesperson for her party between 2001 and 2005, Christensen wrote in the foreword of the policy document that:

There is a threat to cohesion in our community if we do not uphold a picture of our common history and cultural heritage; if we only have a uniform picture of the world that surrounds us; if we lose the desire and the ability to speak sensibly with those who we disagree with yes we can. Democracy and community will not survive in the long run. But when we know our culture and cultural heritage in its diversity, it is the opposite that occurs. (Christiansen 2009, p. 4)

Another rhetorical element underpinning this conventional discourse emphasizes the uniqueness of Danish culture in a turbulent world. In insecure times, facing globalization, the national culture is not only needed, it must also be safeguarded and made available to all Danes. New Danes (immigrants) must also adhere to it.

The second policy program, the Denmark Canon published on 12 December 2016 by Bertel Haarder (2015-2016), a former Minister for Refugees, Immigrants and Integration (2001-2005) for the center-right Liberal Party added a social welfare dimension and arguably a bottom-up perspective. With much sophistry, it set out with the question, "Which social values, traditions or movements that have shaped us in Denmark will you carry through to tomorrow's society?" This question aimed "to raise awareness about the historical and cultural social values, traditions and events that have particularly shaped society and people in Denmark" (www. danmarkskanon.dk).

From the responses offered by 2425 respondents, ten main values ranked by order of importance were identified: (1) the welfare society; (2) Freedom, namely individual freedom; (3) trust; (4) equality before the law; (5) gender equality; (6) the Danish language; (7) associations and voluntary work; (8) liberality/tolerance; (9) hygge "a special way of being together in a relaxing, nice atmosphere"; and (10) Christian heritage or "charity and the Protestant thoughts about the importance of work, the personal responsibility and the equality of all people to God". An information campaign was launched in relation to this, which included roundtable 
discussions at festivals as well as on radio and TV programs and an online digital platform called Denmark Canon (www.danmarkskanon.dk; \#Dkkanon).

Clearly, if one understands these policies as not only continuous but also incremental as it appears, it appears that, similarly to Sweden, the welfare state ranks highest in the world of Danish politicians. Regarding this link between the Danish welfare system and Danish culture and the alleged threats that globalization and immigration pose to its sustainability, the national culture and not multiculturalism is viewed as the ferment needed for its preservation. Consequently, this national culture must be reactivated and broadly diffused. National culture here is coterminous with national identity. The latter is considered as a pillar for cohesion that is essential for the (sustainability) of the welfare system. As the Denmark Canon website states, "The purpose of the canon is also to make it clearer what creates our national identity and cohesion" (www.danmarkskanon.dk). As shown herein, this policy development is used and followed by the mainstream parties in Denmark. In other words, the rhetoric of the DF is embedded in mainstream political discourse in Denmark, whereas in the Sweden, the views of SD stir up emotions and are heavily challenged by the other parliamentary parties, as detailed in the following section.

\subsection{Analysis of the Policy Discourse in Sweden}

The parliamentary debate on the policy proposal, Culture for All (Kultur för alla), took place in the Swedish parliament on 23 February 2017. In this debate, representatives from all the parties in parliament participated with 32 contributions to the debate. In general, the speakers did not tackle culture in abstract ways but rather focused on practical matters. In the initial phase of the debate, culture was connoted with art, museums, and classical music. Thereafter, it shifted to values, heritage, and traditions. The conventional discourse identified was that culture is an engine for the society's development, and welfare sustainability but is removed from citizens' day-to-day concerns.

In the first statement, Marie-Louise Rönnemark from the governing Social Democratic Party (Socialdemokratiska arbetarparti, SAP) held up culture as the engine of society. Rossana Dinamarca from the Left Party (Vänsterpartiet, V) emphasized the importance of having a national culture that represents all the people living in Sweden today. The way into "culture" for her was through diverse avenues, such as, via hip-hop and not merely through official channels such as classical music. Patriarchal structures, class divisions, and structural racism inhibit people from sharing a common national culture made up of various currents. In her view, culture is about democracy, and the "free market" cannot guarantee a "culture for all". Conversely, the representative of the Liberal Party (Liberalerna, L), Bengt Eliasson, made the point that the state should not decide what culture is or should be on a local level. 
This notwithstanding, the intersection between culture and welfare became apparent when Aron Emilsson, the SD speaker for religious matters and the preservation of national heritage took the floor. In his statements, he linked culture to society at large and not solely to practical matters. In line with his party's position, he suggested a cultural canon inspired by Denmark: "If Denmark can do it so can we". He further remarked that "There are five Nordic countries, which have a lot in common. We share the same cultural sphere". In this statement, culture is not merely "crowded out" as a soft issue. Immigration was seen as not only problematic because it increases competition for immigrants on the lower end of the labor market, but also, in this debate, as foremost associated with corroding effects, although this position was opposed by the other parties' representatives.

Marie-Louise Rönnmark (SAP) explained that culture knows no boundaries, and it is despicable to only grant ethnic Swedes free entrance to libraries, museums, and invite them to a joint discussion on what comprises Swedish values. Niclas Malmberg from the Green Party (Miljöpartiet de gröna, MP) remarked that when "Old Swedish" is prioritized, you risk neglecting all the important international influences that have shaped who we are. Per Lodenius, spokesperson for the Centre Party (Centerpartiet, C) on cultural affairs, emphasized that culture is an important aspect of social life and a stimulus for civic participation. Lars-Axel Nordell from the Christian Democratic Party (Kristdemokraterna, KD) stated that culture is a meeting point for organizations and individuals in civil society.

The views of political representatives diverged along the left/right ideological spectrum on the connotations of culture, how much influence the state should have on local cultural practices, and what culture should be. However, everyone (except the representative from the right-wing populist SD) agreed that cultural policies should be reflective of all the diverse layers of the population in Sweden, including immigrants, and not only, those residing in the urban areas, for example. The conventional discourse is thus to facilitate integration among diverse parts of the people living in Sweden. The intersection between welfare and culture gave way to more abstract discussions about how social cohesion can best be fostered, especially in insecure times, and how unity in terms of a common identity and history must be emphasized. The discussion of the Danish cultural canon mooted by the SD representative became the focus of deliberations. This is also reflected in the blogosphere, as analyzed in the following sections.

\subsection{Analysis of the Blogosphere in Denmark}

Martin Henriksen's Facebook page has a high "view rate". It has a significant number of followers (26,412 as of 10 July 2019) and "Likes" (25,699 as of 10 July 2019). From the launch of his page on 15 July 2015 until 11 July 2019, he wrote eight posts on welfare, which our search with the keyword "velfard" uncovered. Each of his posts has had no less than 200 "likes" and none had gone unanswered. 
Their lines of argumentation reveal strong similarities with Therese Borg's blog (see next section). The conventional discourse - that Denmark cannot afford multiculturalism - exalts welfare chauvinism. Immigration is viewed as a zero-sum game for the welfare state, notably for its financial sustainability and pensioners' well-being.

In one post from 16 March 2017, Henriksen writes that:

DF's policy works! In the election campaign, we promised to work to tighten up the asylum system so that we get fewer asylum seekers to the country - and thus can spend more money on welfare instead. Last year, far fewer asylum seekers came to Denmark than expected, and thus there are now DKK 400 million more in the treasury, which can be used for welfare, among other things. We are continuing the fight to implement more udlaendingestramninger so that we can get asylum numbers much lower and more money for welfare. Just like we promised before the election. Do you agree with DF that Denmark needs far more immigration restrictions and a strengthened and permanent border control so that we can get more money for welfare? ${ }^{5}$

In another post drawn from his opinion piece in the newspaper Berlinske Tidende (Henriksen 08 November 2017) with the title "Drop snakken om velfard vs skattelettelser - her er det vigtige spфrgsmål!" (Drop talk about welfare vs tax cuts here's the important question!), Henriksen writes that immigration is the biggest threat to the welfare system. Alongside many grievances, he cites a report from the Ministry of Finance according to which non-Western immigration has cost DKK 33 billion in $2014 .^{6}$ The most popular reaction among readers is that of A.D. (anonymized) with 41 replies. It deals with the introduction halal food in "dagis" (nursery schools). A.D. writes:

that we, as Danes, have to forego our culture to take care of Muslims and therefore we are happy to remove pork in the institutions. It is simply absurd that such a religion should dictate what is right and wrong in Denmark. Totally absurd and more absurd it becomes when Christians are more or less forced to eat food blessed in the name of an idol. It's called idolatry. ${ }^{7}$

In an image that Henriksen posted on his Facebook profile on 31 May 2017, it is stated that stopping asylum will release enough money to increase old-age pension by DKK 11000 (about $€ 1474$ ). Henriksen's argument is that it is not possible to both fund the welfare state for pensioners and cater to immigrants' needs. ${ }^{8}$

Conversely, as we found out in the study of Swedish politicians' conventional discourses, which we discussed in the previous section, issues concerning the welfare state are dissociated from those of multiculturalism. Multicultural policy, discourse, and even its adverse effects mentioned before are not discussed. Multiculturalism is a non-starter. For example, in another image featuring Henriksen

\footnotetext{
${ }^{5}$ https://www.facebook.com/pg/Martin-Henriksen-1604502423155684/posts/?ref=page_internal ${ }^{6} \mathrm{https}: / /$ www.facebook.com/pg/Martin-Henriksen-1604502423155684/posts/?ref=page_internal

${ }^{7}$ https://www.facebook.com/1604502423155684/photos/a.1607823059490287/ $2138790309726890 /$ ?type $=3 \&$ theater

${ }^{8}$ https://www.facebook.com/1604502423155684/photos/a.1622432261362700/ $2297663740506212 /$ ?type $=3 \&$ theater
} 
posted on 03 September 2018, [Muslim] immigrants are urged to "throw away the [Muslim] scarf and join Denmark". It is accompanied by the following text:

Danish People's Party has launched a new nationwide campaign. The Danish People's Party would like people with an immigrant background to become part of Denmark. but it requires personal effort to adopt Danish culture and join the society. It has always been so. Agree? Please share. ${ }^{9}$

The same image was used in a subsequent post from 1 May 2019 in which Henriksen wrote:

In the latest edition of Sports Illustrated there is a woman wearing the Muslim scarf. It rightly creates a lot of debate. Read the following: https://ekstrabladet.dk/nationen/megasmuk-muslimsk-model-skaber-debat-jeg-forstaar-det-ikke/7615648. Unfortunately, there is still a good reason to make sure that the Muslim scarf does not belong in neither a Western nor Danish context. It's a totalitarian, misogynist and actually also a symbol of hostility against men. It is simply incompatible with Danish culture and the world heritage that Denmark rests on. Agree? Please share. ${ }^{10}$

Unlike other posts, there was a strong pushback by visitors against this post. Most reactions oppose Henriksen's statement with an equally harsh tone. They defend the freedom of women to choose what to wear and relate the idea to totalitarianism, fascism, and even Nazism. The DF is accused of focusing on an issue of little importance. ${ }^{11}$ This indicates the presence of a growing counter-movement to radical ideas in the Danish blogosphere.

\subsection{Analysis of the Blogosphere in Sweden}

The welfare state requires cultural conformism to distribute resources evenly in the population, indicative of the corroding effects of migration. In one entry on a recent proposal on enhancing social cohesion in the local community, it is apparent that Therese Borg and the SD would like to enhance the integration of citizens in the national community. The ambition is hampered by the fact that the society cannot guarantee support for its native citizens, and the non-natives are either culturally alienated or alienated in terms of welfare (or both) from the rest of the society ${ }^{12}$ (Borg 09 November 2011). According to her, the reason is "mass immigration". Native pensioners and the poor should be helped before we help "the others"; hence, we need to maintain stable welfare institutions in the national community.

\footnotetext{
${ }^{9}$ https://www.facebook.com/1604502423155684/photos/a.1607823059490287/ $2138790309726890 /$ type $=3 \&$ theater

${ }^{10} \mathrm{https}$ ://www.facebook.com/1604502423155684/photos/a.1607823059490287/ $2282498652022721 /$ ?type $=3 \&$ theater

${ }^{11}$ https://www.facebook.com/1604502423155684/photos/a.1607823059490287/ $2282498652022721 /$ ?type $=3 \&$ theater

${ }^{12} \mathrm{https} / / /$ thereseborg.wordpress.com/2011/11/09/som-man-fragar-far-man-svar/
} 
In the lines of argumentation, the conventional discourse is that natives should be helped first (pensioners and the poor). The SD has brought this to the forefront of politics many times. In Borg's view, many are waking up, albeit slowly, to the notion that they had been clinging on to idealistic dreams ${ }^{13}$ (Borg 12 June 2011). Immigration costs the society more money than it is actually worth. In order to maintain trust in the welfare institutions, society cannot sponsor divergent cultural practices. In a discussion on boys' circumcision, associations are made between other cultures and the mistreatment of boys. In a blog entry comment, B.A. (anonymized) says, "this hatred cannot be ignored, neither can the violence. In our roughest city districts such as Rosengård, Rinkeby, and Lövgärdet, Bagdad-style gang culture is alive"14 (Borg 22 November 2011).

The alleged crisis of the welfare state is a recurrent topic. Statements are made about local health center closures, while those higher up in the hierarchy misuse money. Many blog posts are concerned with welfare cuts, criticizing welfare money being spent on illegal immigrants instead. Poor students (who are deemed most deserving of help) are pitted against illegal immigrants (who are deemed not entitled to welfare privileges). Much space is devoted by Borg to the SD proposal for estimating the costs of multiculturalism. The conventional discourse is that We cannot afford multiculturalism. The differences between cultures are explicit with those who comment on her blog, while the actual blog entries communicate the same message in line with the basic tenets of neo-racism but with slightly less vigor (Hellström 2016).

Other common themes in her blog entries are sexual harassment and healthcare. Typically, these are reports on doctors of immigrant background who offend their female patients ${ }^{15}$ (Borg 30 July 2011). Concerns are voiced regarding the lack of efficient communication between the immigrant doctor and the native patient ${ }^{16}$ (Borg 17 May 2011; see also Edenborg Chap. 7, in this volume). The argument is that the immigrants lack proper language training. The political claim being made in that blog post is that more native doctors should be employed or trained. Such examples are taken as a proof that the natives and the immigrants cling to different gender ideologies. In another blog post, Borg stresses the need to encourage immigrant girls to play soccer. Replies by her readers cite, more explicitly, cultural differences as the reason for their low participation rate $^{17}$ (Borg 14 March 2012).

In her view, multiculturalism represents the opposite of solidarity and joint values. Instead of multiculturalism, Swedes must learn to appreciate their own culture. The conventional discourse is that "Culture should be for everyone and not divided

\footnotetext{
${ }^{13} \mathrm{https}$ ://thereseborg.wordpress.com/2011/06/12/over-50-av-invandrarna-ar-beroendeav-socialbidrag/

${ }^{14} \mathrm{https}$ ///thereseborg.wordpress.com/2011/11/22/motion-om-omskarelse-av-pojkar/

${ }^{15} \mathrm{https} / /$ thereseborg.wordpress.com/2011/07/30/interpellationsdebatt-med-anledning-av-en-lakares-sexuellaovergrepp-mot-patienter/

${ }^{16} \mathrm{https}$ ://thereseborg.wordpress.com/2011/05/17/tre-nya-motioner-inlamnade-i-landstinget/

${ }^{17} \mathrm{https}$ ://thereseborg.wordpress.com/2012/03/14/invandrarflickors-laga-deltagandebehover-utredas/
} 
among different sections in society, rather it must be framed as one national culture". Governmental policies are harshly criticized. It is alleged that Sweden is run by a coalition of bourgeois parties with an elitist view on culture. Instead of provocative art, cultural politics should be about cherishing what native culture has created through generations and what the common man appreciates ${ }^{18}$ (Borg 9 November 2011).

Several blog posts are about the exhibition "Thou Ancient, Thou Free", the de facto Swedish national anthem (Du gamla du fria), concerning Swedish culture, curated by the Eskilstuna Museum. In this discussion, the most prevalent opinion was that celebrating midsummer is more Swedish than celebrating Ramadan. Borg suggested that most of the Swedish population agrees on this point ${ }^{19}$ (Borg 25 February 2011). The conventional discourse thus says that "Our common cultural heritage is important to recognize".

\subsection{Conclusions}

Our analysis has revealed that the discourses on immigration, culture, and welfare and their embedded meanings in Denmark and Sweden share some similarities, and certainly, some important differences as well. They are similar in that they both emphasize the importance of culture for societal cohesion and the sustainability of the welfare state in insecure times. However, they differ in that assimilation is a mainstream policy in Denmark but not to the same extent in Sweden, as illustrated in the following Table 2.1.

To argue for assimilation is accepted wisdom in Denmark, while in Sweden, the focal point is on multiculturalism. The borders of normality are not the same. Politicians in Sweden have been preoccupied with practical concerns regarding dayto-day access to cultural goods. Although they show concern about the negative effects of social fragmentation, this is to a lesser extent than their Danish counterparts. While in Denmark, ethnocultural diversity is seen as antithetic to social cohesion across the political landscape, in Sweden, opinions vary along ideological lines. However, when the refugee crisis struck in autumn 2015, Sweden's immigration policy became more restrictive and less generous: Border controls on the Öresund Bridge were introduced and asylum rights were lowered to the EU minimal requirements (Law 2016: 752). Nevertheless, this has not dented Sweden's reputation as a generous country for refugees, alongside Germany. This is because, although Sweden has restricted its immigration policy, it has not changed its integration policy to a significant extent and the changes are not seen on the ground.

The conventional discourse among established parties in Denmark is accentuated in the blogosphere. Online strategies correlate with mainstream policies; for

\footnotetext{
${ }^{18} \mathrm{https}$ ://thereseborg.wordpress.com/2011/11/09/som-man-fragar-far-man-svar/

${ }^{19} \mathrm{https}: / /$ thereseborg.wordpress.com/2011/02/25/du-gamla-du-fria/
} 
Table 2.1 Summary of conventional discourses

\begin{tabular}{|c|c|c|}
\hline & Denmark & Sweden \\
\hline \multirow[t]{3}{*}{ Policy arena } & $\begin{array}{l}\text { Danish culture is unique and reflects a } \\
\text { unique people. }\end{array}$ & $\begin{array}{l}\text { Culture is an engine for society, but } \\
\text { cultural policy is remote from } \\
\text { citizens' day-to-day needs. }\end{array}$ \\
\hline & $\begin{array}{l}\text { In insecure times and facing globalization, } \\
\text { we need to safeguard Danish national } \\
\text { culture and make it available to all Danes. } \\
\text { New Danes (immigrants) must adhere to it. }\end{array}$ & $\begin{array}{l}\text { In insecure times, we need to } \\
\text { emphasize what unites us in terms } \\
\text { of common identity and history. }\end{array}$ \\
\hline & Enable assimilation. & $\begin{array}{l}\text { Facilitate integration between } \\
\text { people of all the layers of the } \\
\text { population. }\end{array}$ \\
\hline \multirow[t]{4}{*}{ Blogosphere } & $\begin{array}{l}\text { We should help native citizens first } \\
\text { (pensioners and the poor). }\end{array}$ & $\begin{array}{l}\text { We should help native citizens first } \\
\text { (pensioners and the poor). }\end{array}$ \\
\hline & Denmark cannot afford multiculturalism. & $\begin{array}{l}\text { Sweden cannot afford } \\
\text { multiculturalism. }\end{array}$ \\
\hline & $\begin{array}{l}\text { Culture should be for everyone and not } \\
\text { divided into different sections of society; it } \\
\text { must be framed as one national culture. }\end{array}$ & $\begin{array}{l}\text { Culture should be for everyone and } \\
\text { not divided into different sections of } \\
\text { society; it must be framed as one } \\
\text { national culture. }\end{array}$ \\
\hline & $\begin{array}{l}\text { Our common cultural heritage is important } \\
\text { to recognize. }\end{array}$ & $\begin{array}{l}\text { Our common cultural heritage is } \\
\text { important to recognize. }\end{array}$ \\
\hline
\end{tabular}

example, the argument that society cannot afford multiculturalism is explicit and sometimes expressed in vulgar terms. Also, the claim that the promotion of ethnocultural diversity can counter patriarchy or racism is ridiculed. The same goes for the recognition of minority groups' rights. Conversely, these expressions rest on the notion of a fixed national heritage in need of urgent preservation, and the revalorization of the national culture is considered a powerful response. This is manifest in the implementation of cultural and normative canons, and similar expressions are found in the Swedish blogosphere. However, our examination shows that what is tacitly agreed upon in mainstream Danish politics is widely contested in Swedish politics. Only time will reveal the right and probable path ahead.

\section{References}

Andersen, C. (2005, 28 September). Kanon-medlemmer truer med at gå. Politiken. http://politiken. dk/kultur/ECE124540/kanon-medlemmer-truer-med-at-gaa/. Accessed 28 Mar 2018. 
Banting, K., \& Kymlicka, W. (2006). Multiculturalism and the welfare state: Recognition and redistribution in contemporary democracies. Oxford: Oxford University Press.

Bevelander, P., \& Hellström, A. (2019). Pro- and anti-migrant mobilizations in polarized Sweden. In A. Rea, M. Martiniello, A. Mazzola, \& B. Meuleman (Eds.), The refugee reception crisis: Polarized opinions and mobilizations (pp. 75-94). Bruxelles: Éditions de l'Université de Bruxelles.

Christiansen, C. (2009). Forord. In Kulturministeriet, Kultur for alle. Kultur i hele landet. Köpenhamn.

Danish Ministry of Culture. (2002, 25 January). Pressemeddelelse: Nye Tiltag og faelles besparelser på kulturen. http://kum.dk/nyheder-og-presse/pressemeddelelser/2002/januar/nyetiltag-og-falles-besparelser-pa-kulturen/. Accessed 29 Apr 2018.

Danish Ministry of Culture. (2010). Om Kulturkanonen. http://kulturkanon.kum.dk/Services/ Om-Kulturkanonen/. Accessed 20 Jun 2018.

Danmarkskanon. (2016). What makes us who we are. https://www.danmarkskanon.dk/om-danmarkskanonen/english/. Accessed 28 Mar 2018.

Duelund, P. (2009). National cultural canons as a cultural policy response to globalisation? http:// www.culturalpolicies.net/web/compendium-topics.php?aid=149. Accessed 28 Mar 2018.

Esping-Andersen, G. (1990). The three worlds of welfare capitalism. Princeton: Princeton University Press.

Hellström, A. (2016). Trust us: Reproducing the nation and the Scandinavian nationalist populist parties. New York: Berghahn Books.

Hellström, A., \& Nilsson, T. (2010). We are the good guys: Ideological positioning of the nationalist party Sverigedemokraterna in contemporary Swedish politics. Ethnicities, 12(1), 55-76.

Henriksen, M. (2019a). Photo available at https://www.facebook.com/1604502423155684/photos/ a.1607823059490287/2138790309726890/?type=3\&theater. Accessed 23 Aug 2019.

Henriksen, M. (2019b). Photo available at https://www.facebook.com/pg/MartinHenriksen-1604502423155684/posts/?ref=page_internal. Accessed 23 Aug 2019.

Henriksen, M. (2019c). Photo available at https://www.facebook.com/1604502423155684/photos/ a.1622432261362700/2297663740506212/?type=3\&theater. Accessed 23 Aug 2019.

Law (2016:752). Om tillfälliga begränsningar av möjligheten att få uppehållstillstånd $i$ Sverige.

Mazzoleni, G., \& Bracciale, B. (2018). Socially mediated populism: The communicative strategies of political leaders on Facebook. Palgrave Communications, 4(50), 1-10. https://doi. org/10.1057/s41599-018-0104-x.

Mikkelsen, B. (2005). Speech at the conservative party annual conference. https://dansketaler.dk/ tale/landsmoedet-2005/. Accessed 25 Oct 2019.

Norocel, O. C. (2016). Populist radical right protectors of the folkhem: Welfare chauvinism in Sweden. Critical Social Policy, 36(3), 352-370.

Petersen, S. (2006, 9 March). Ny uro i kanon-projek [New concerns in the canon project]. Berlingske Kulturt. http://www.b.dk/kultur/ny-uro-i-kanon-projekt. Accessed 21 Apr 2018.

Pettersson, K. (2017). Save the nation! A social psychological study of political blogs as a medium for nationalist communication and persuasion. Helsinki: University of Helsinki, Department of Social Research.

Puri, J. (2004). Encountering nationalism. Oxford: Blackwell Publishing.

SCB. (2019). Statistiska centralbyrån. https://www.scb.se/hitta-statistik/sverige-i-siffror/manniskorna-i-sverige/utrikes-fodda/?fbclid=IwAR2IOXs3AO60UOBgyirNgK-7Z-dAW5gW8K11q2rL3ZvhWyEYB8M65FsD0sI. Accessed 7 March 2020. 
Schierup, C., Hansen, P., \& Castles, S. (2006). Migration, citizenship, and the European welfare state. A European dilemma. Oxford: Oxford University Press.

Statistik Denmark. (2019). https://www.dst.dk/Site/Dst/Udgivelser/nyt/GetAnalyse.asp $\mathrm{x}$ ? cid=32554\&fbclid=Iw AR1UfDPF7ufbTgRSmv9ZsEdR0dD5wddsLjr_W4GVGwAVCBYay2sJaYEQgA. Accessed 8 March 2020.

Strauss, C. (2012). Making public opinion work: American discourses about immigration and social programs. Cambridge: Cambridge University Press.

Tawat, M. (2017). The birth of Sweden's multicultural policy. The impact of Olof Palme and his ideas. International Journal of Cultural Policy, 1-15. https://doi.org/10.1080/10286632.201 7.1335719 .

Open Access This chapter is licensed under the terms of the Creative Commons Attribution 4.0 International License (http://creativecommons.org/licenses/by/4.0/), which permits use, sharing, adaptation, distribution and reproduction in any medium or format, as long as you give appropriate credit to the original author(s) and the source, provide a link to the Creative Commons license and indicate if changes were made.

The images or other third party material in this chapter are included in the chapter's Creative Commons license, unless indicated otherwise in a credit line to the material. If material is not included in the chapter's Creative Commons license and your intended use is not permitted by statutory regulation or exceeds the permitted use, you will need to obtain permission directly from the copyright holder. 